\title{
A importância da pesquisa experimental
}

A cirurgia plástica é reconhecida por suas características de inovação tecnológica. Muito deste desenvolvimento foi baseado na inventividade do cirurgião. São diversas as situações nas quais o cirurgião desenvolve técnica ou método de tratamento demandados por um evento de dificuldade momentânea. A partir deste ponto, analisa sua ideia e tenta reproduzi-la de forma padronizada em série de casos. Convencido da efetividade de sua ideia, o cirurgião aprofunda seus conhecimentos, aplicando-os em estudos experimentais que comprovem efetivamente sua impressão inicial.

Se este raciocínio for apresentado a um pesquisador clínico ou de área básica, será visto como algo tendendo ao absurdo, diametralmente oposto ao conceito da pesquisa científica baseada em evidências. No entanto, isto ocorre, é real.

Não é desejável, mas é fato. É fato, porém tem sido aprimorado e ajustado à realidade científica atual. Estudos experimentais em cirurgia plástica embasando a pesquisa clínica têm ocorrido em diversas áreas, como as pesquisas em engenharia de tecidos, biologia óssea, fisiopatologia das queimaduras, fisiologia dos retalhos, resposta tecidual à isquemia, uso de células-tronco e estudos sobre angiogênese.

A interação entre pesquisa experimental e prática clínica é fundamental na formação do cirurgião plástico, ainda que seu objetivo profissional seja iminentemente clínico. A partir da experiência científica, o cirurgião em formação consolida suas bases teóricas, estimula seu raciocínio e, efetivamente, exerce a profissão de forma completa.

As publicações experimentais, entretanto, têm sido preferencialmente publicadas em revistas de alto impacto, porém diferentes daquelas mais lidas pelo próprio cirurgião plástico. É missão deste Editor a busca contínua pelo estímulo ao pesquisador, visando resgatar o interesse em divulgar estudos experimentais em nossa Revista, lembrando que as portas estão abertas para a submissão de estudos experimentais em Cirurgia Plástica.

\section{Dov Charles Goldenberg}

Editor Associado 